\title{
The Effect of Human Capital Development on Strategic Renewal in the Egyptian Hospitality Industry: The Moderating Role of Dynamic Capabilities
}

\author{
Amira M. Omar ${ }^{1}$ \\ ${ }^{1}$ Faculty of Economics and International Trade, Egyptian Chinese University, Cairo, Egypt \\ Correspondence: Amira M. Omar, Faculty of Economics and International Trade, Egyptian Chinese University, \\ Cairo, Egypt.
}

Received: June 24, 2021

Accepted: July 15, 2021

Online Published: July 30, 2021

doi:10.5539/ibr.v14n9p38

URL: https://doi.org/10.5539/ibr.v14n9p38

\begin{abstract}
Purpose: the primary goal of this research is to provide insight into the effect of human capital development on strategic renewal in the Egyptian hotel industry. In addition, to examine the effect of dynamic capabilities as a moderating variable in the relationship between human capital development and strategic renewal.

Methods and tools: questionnaires were distributed based on a simple sampling method and collected in the Egyptian hospitality industry. 310 questionnaires were distributed, and 204 usable samples were obtained, yielding a $66 \%$ response rate from those who agree to participate. The Partial Least Square-Structural Equation Modeling (PLS-SEM) method has been used for analyzing the data and testing our hypotheses. The analysis of this paper was done using SPSS V. 23 for both descriptive and inferential statistics and Smart PLS V.3.3.3 for PLS-SEM analysis.

Results: this study indicates that human capital development has a statistically significant effect on Strategic Renewal; also, the findings observe that Dynamic Capabilities have a statistically significant impact on Strategic Renewal. And the Moderating Effect of dynamic capabilities not approved.

Theoretical and empirical contribution: The conceptual model with statistical results that emphasizes the significance of human capital development for the strategic renewal of business enterprises in the Hospitality field of developing countries has been investigated in this study. Human capital development has previously been highlighted, but its impact on strategic renewal has not been extensively investigated. Besides, this study provides valuable insights for decision-makers. As recommends that hotel managers consider human capital development and present it as a vital part of strategy formulation.
\end{abstract}

Keywords: human capital development, strategic renewal, dynamic capabilities, hospitality industry

\section{Introduction}

The concept of strategic renewal is well highlighted. However, to a constrained level alarming for the hotel sector, only a minimal focus has been given to the hospitality industry concept's antecedents and consequences (Schmitt et al., 2018). Thus, this study aims to resolve the lack of knowledge relating to strategic renewal in the hospitality industry.

Human capital development is described as practices aimed at developing awareness, enhancing skills, reinforcing ethics, and supporting behaviors to maximize the abilities of an organization's employees. The provision of training, and learning, to improve employee, team, and organizational success is a part of an organization's human capital development (Alo, 2000). Kuznetsova et al. (2019) identified human capital development as proceeding through training or learning to enhance knowledge and abilities. Although, In the hotel sector, it is observed that there is a shortage of studies on human capital development. Accordingly, because of this research gap, this study aimed to figure out the role of human capital development in the strategic renewal implementation inside the Egyptian hotel sector.

The company's resource-based view (RBV) has transformed into dynamic capabilities (Wernerfelt, 1984). RBV supporters claim that unique, exceptional, irreplaceable, and non-substitute capital can be both an outstanding output source and a sustainable source of competitive advantage for the company (Barney, 1991). The dynamic 
capabilities gave value to the concept of RPV as it transformed the static view into a dynamic view of resources and thus helped in achieving a competitive advantage (Barney, 2001). According to Danneels (2002), a dynamic view is vital for the RBV to consider how companies change quickly by resource allocation and recruitment. Because firms must always reconstruct and reorganize everything if they are to sustain.

Garavan et al. (2016) described those dynamic capabilities are essential for kicking off the strategic renewal process. Thus, the dynamic capabilities help to enhance human capital development and strategic renewal. Consequently, Dynamic capabilities are included in this study's hypothesized model to examine its role in reinforcing the relationship between human capital development and strategic renewal in the hospitality industry.

Hotels are among the most critical industries for employment because they serve as centers for everything else. As a result, the gradual expansion of hotel space has mirrored foreign visitors' rapid growth (Zaytoun et al., 2010). Essentially, they are essential to tourist attractions excelling. The Egyptian market was severely impacted by the global financial crisis in 2008, the January 25 Movement in 2011, and the Russian airplane disaster of October 2015. This depression hurt the demand and supply in the hospitality industry (Mohamed,2016). Besides, the COVID 19 pandemic which still affects all sectors in the Egyptian market since 2019. In 2016, it was estimated that the number of hotels and resort districts declined due to the crisis. Over 40 hotels have shut down in Nuweiba and Taba in South Sinai and 27 hotels in Marsa Alam. And more than 250 hotels have completely stopped operating (Al-Shuwaikhi, 2015). Therefore, this study's main aim is to add to what has already been identified about the hospitality sector's strategic renewal via human capital development and investigating the moderating effect of dynamic capabilities on the relationship between human capital development and strategic renewal. This study focuses on present a strategic renewal framework for the Egyptian hospitality sector, which is currently lacking in the literature. The component of this study is organized as follows: the first section is the literature review. The following sections explain the research problem, establish research hypotheses, and research framework, and discuss the research methodology. The last sections contain the analysis, contributions, and conclusion.

\section{Literature Review}

\subsection{Human Capital Development}

Researchers have been involved in studying human capital, Including education, knowledge, skills, and experiences, for many decades. (Unger, J. M.; et al., 2011). Felício, Couto, and Caiado (2014) considered that human capital is formed by (1) knowledge, (2) management/leadership, technical/technological and industry experience, (3) professional proficiency, and (4) cognitive ability, including variables related to strategic decision-making, perception of threats and risk, innovativeness, and detection and exploitation of market opportunities. Furthermore, Human capital is generally the workforce's capability by using their education, knowledge, and expertise to produce real incomes; it relates to the know-how, abilities, experience, and skills of employees (Dzinkowski, 2000). Human capital attributes, including education, skills, and knowledge, have long been debated to be a key business growth element (Sexton \&Upton, 1985; Florin, Lubatkin, \& Schulze, 2003). In actuality, the most used screening criteria among venture capitalists are leadership skills and expertise (Zacharakis \& Meyer, 2000). In particular, with respect, the Authors have suggested that human capital will play a much more significant role in shaping the future as knowledge-comprehensive tasks can continually expand in most working environments. (Bosma, van Praag, Thurik, \& de Wit, 2004; Sonnentag \& Frese, 2002; Honig, B., 2001).

The concept of human capital can be understood as a set of intangible resources needed in the labor factor to improve productivity (Goldin 2016). These are associated with knowledge and skills acquired through education, experience, and healthcare (Schultz 1961; Becker 1962). Likewise, Tus, Benos, and Zotou (2014) defined human capital as the set of knowledge, skills, competencies, and abilities embodied in individuals. They acquired, through education, new learning, training, medical care, and experience. As reflected in an individual's skills and knowledge, human capital is less tangible than physical capital. On the other hand, Physical capital is tangible and has been expressed in an identifiable material type. (Coleman, J, 2009)

Becker, G., 1962 declared that Individuals vary significantly in their financial well-being. When their people had much more physical capital than most others, economists attributed these variations to variations in the amount of physical capital. However, this has become obvious from income growth analyses that variables rather than just physical capital play a significant role than commonly thought, concentrating emphasis on less visible capital, such as the skills and knowledge they provide.

The human capital theory, which originated in the work of Mincer (1958), Schultz (1961), and Becker (1962), stated that people acquire skills (human capital), increasing their proficiency and thus productivity and resulting 
in a higher income (Fix, 2018). Human capital theory suggests that individuals try to obtain compensation for their human capital investments. Thereby, people, given their human capital, attempt to maximize their economic return. (Becker, 1964).

Employees' particular range of abilities, expertise, and knowledge comes with training and advanced learning, referred to as human capital development. According to Smith (2010), human capital is created through structured education and training that enhances people's knowledge, expertise, and capacity to control resources, control procedures, forecast performance, and drive creativity and improvement. Also, several studies (Cummings et al., 2010; Ployhart et al., 2014) have shown that human resource growth in the context of structured education and training has a significant and beneficial effect on a range of performance outcomes.

\subsection{Strategic Renewal}

Strategic renewal is an essential topic in a variety of scientific papers and other organizations. Since it helps organizations shift their past actions by changing their strategic purpose and capabilities, we may start by defining the two terms that constitute strategic renewal to define strategic renewal. The renewal activity means a firm conducts to modify its path dependence (Volberda et al., 2001). It concerns the redevelopment, reallocation, or Modification of the firm's existing organizational attributes (Agarwal \& Helfat, 2009). Companies could discover and develop all-new methods of utilizing the skills and approaches they already have by using strategic renewal (Floyd \& Lane, 2000). The word strategic means that organizations rebuild their main ideas on which they are constructed (Guth \& Ginsberg, 1990). 'Strategic' thus relates to actions aimed at modifying the necessary skills that distinguish an organization from its rivals. (Flier et al., 2003). The idea of 'strategic renewal' is only considered strategic as it covers the whole organization (Crossan et al., 1999).

Although it has been widely recognized and strongly valued, there is no clear definition of what strategic renewal entails and how it varies from other aspects of strategy (Verbeke et al., 2007; Agarwal \& Helfat 2009). For example, numerous studies have described strategic renewal as a particular form of strategic change (Burgelman,1991). A management approach that encourages modifications in the core competencies of an organization (Floyd \& Lane, 2000), Transformation within business' resource patterns' (Stopford \& Baden-Fuller, 1994), and aligning management capabilities with the environment (Flier et al., 2003).

In terms of the renewal process's definition, the sophistication of the design and sequence of behavior and variables that affect them is very challenging to determine (Walas-Trębacz, 2008). One of the suggestions is Chowdhury's (2002) four-stage definition, which involves balance, decline, renewal, and the impact of renewal. In the next version, the strategic renewal process's length was enhanced to eight phases in reaction to uncertainty. Besides, management can use three viewpoints on strategic decisions, emerging, rational, and situational (Hurst,1995). Mielcarek (2018) proposed two renewal criteria: implementing and value creation. The implementing criterion allows distinguishing directed renewal and emergent renewal. Besides, it's a formalized, planned, centralized transition. These practices are initiated and approved by top management. on the other hand, the emergent strategy assumes a greater degree of decentralization of the decisions, and initial targets are set without specific plans. The second criterion to defining the strategic renewal is value creation, which includes capturing and generating value.

The determinants of strategic renewal are a significant concern in many studies related to organizational development. For instance, Crossan and Berdrow (2003) stressed the significance of organizational learning in the strategic renewal process. Besides, Strategic renewal and the availability of prospects in the increasingly complex environment were related by Schmitt et al. (2016). Dutta (2013) emphasizes the significance of environmental dynamism in the strategic renewal process. Warner and Wager (2019) concentrated on the essential role of dynamic capabilities in executing strategic renewal.

\subsection{Dynamic Capabilities}

The core of the resource-based view (RBV) is resources. They are the physical, human, and operational resources organizations can utilize to conduct value-creating initiatives (Barney, 1986). In addition, these provide localized skills and abilities or "qualifications" that are vital to a firm's competitiveness. Consequently, resources act as the base for unique value-creating techniques and operation structures that target particular sectors and consumers in unique ways, resulting in strategic advantage (Porter, 1996; Womack et al., 1991).

Dynamic capabilities are the corporation's capacity to modify its resources to shape a new approach to build value (Grant, 1996; Pisano, 1994). They are fundamental since they drive the development, evolution, and recombination of many other resources to create new critical success factors (Teece et al., 1997). According to Eisenhardt (2000), companies utilize resources - specifically the techniques to combine, rearrange, obtain and 
allocate resources to meet and even produce a market shift. Dynamic capabilities thus would allow businesses to continue adapting and reacting to different markets and customers.

Some types of dynamic capabilities can manage resources. Production process practices, for example, are a dynamic capability in which managers integrate their different abilities and technical experiences to create revenue-generating services and goods (Helfat \& Raubitschek, 2000). Other dynamic capabilities are concerned with resource restructuring across organizations. For example, managers use transfer processes such as duplication to replicate, shift, and recombine resources, especially knowledge resources, within the company (Hansen, 1999; Hargadon \& Sutton, 1997).

\section{Research Problem}

The deliberation on a strategic renewal of the hotel industry has received considerable attention. However, this deliberation is insufficient for the hotel industry because of its underdevelopment (Schmitt et al., 2018). In the relevant field of knowledge, the factors of strategic renewal are heavily discussed. For example, Crossan and Berdrow (2003) illustrated the importance of organizational learning in extending the strategic renewal phase. Schmitt et al. (2016) correlated strategic renewal with the accessibility of opportunities in the changing climate. In improving the mechanism of strategic renewal, Dutta (2013) emphasizes the value of environmental dynamism. Warner and Wager (2019) stressed the critical position of Dynamic capabilities in getting into the strategic transformation mechanism. Martin-Rios (2020) asserts that concerning the hotel sector, all players in the hotel industry, i.e., airline companies, restaurants, motels, hotels, are searching for short-term strategies that could create sufficient business opportunities to achieve success in the market. Also, the sector reports that managerial problems have influenced them to predict and react to shift patterns in the market environment.

Other considerations play an essential role in strategic renewal. The question, though, most researchers have overlooked the role of human capital and its development as a requirement for every firm's strategic renewal. For example, while Jarvi and Khoreva (2020) lately emphasized the value of talent management in improving strategic renewal, he still neglected the impact of human capital development in improving strategic renewal processes. Besides, Kuznetsova et al. (2019) describe human capital as acquiring and accumulating skills and expertise via education and training. Yet, there is little available literature that describes the strategic renewal procedure in the hotel sector through human capital development.

Easterby-Smith \& Prieto (2008) defined dynamic capabilities as the firm's ability to adapt to changes and improve its internal and external capabilities to cope with uncertainty. Aso, Garavan et al. (2016) illustrated how dynamic capabilities are required as a basis for being strategic. Therefore, the dimensions among dynamic capabilities play a crucial role in reinforcing human capital and strategic renewal.

Considering these factors, the primary study aim of this paper is to resolve this gap in research and to provide insight into how human capital development affects strategic renewal in the Egyptian hotel industry. Furthermore, the dynamic capacities of the human resources are included in the hypothesized model. The mediating role of dynamic capabilities on the relationship between human capital development and strategic renewal is analyzed. And therefore, the main research question is:

What is human capital development's effect on the firm engaging in strategic renewal in the Egyptian hospitality industry? What is the moderating role of Dynamic capabilities on the relationship between human capital development and strategic renewal?

\section{Analytical Framework and Development of Hypotheses}

In the light of the previous literature review, research problem, and research gap Accordingly, we propose the following hypotheses and theoretical framework:

H1: A higher degree of human capital development positively influences the probability.

of a firm engaging in strategic renewal.

H2: Dynamic capabilities have a moderating effect on the relationship between human capital development and strategic renewal. 


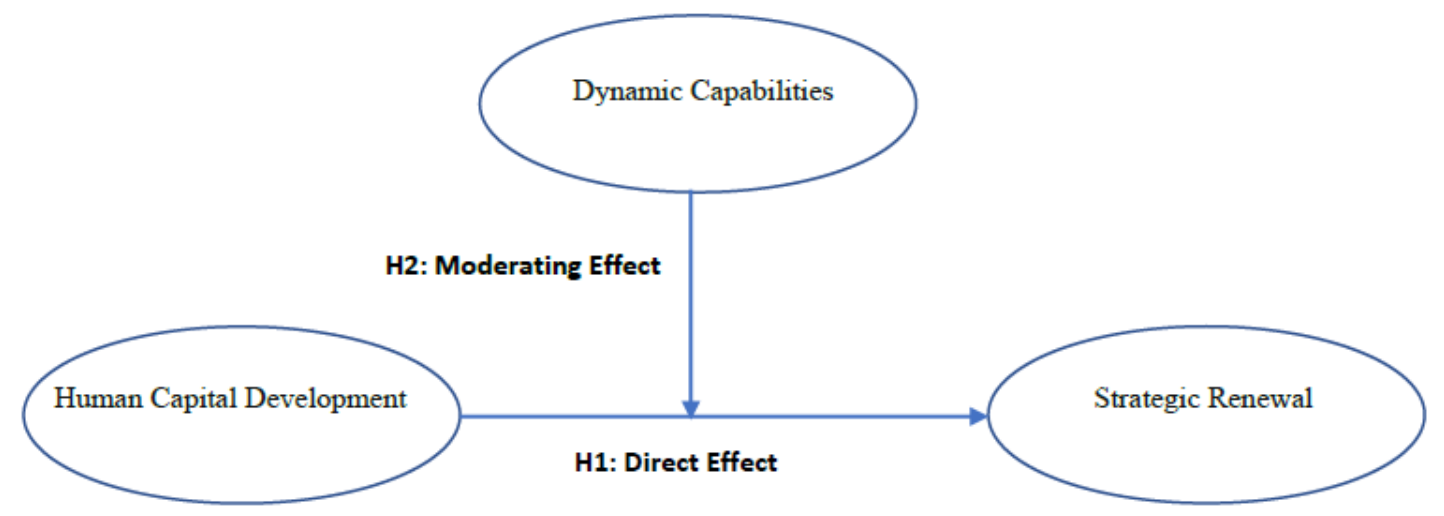

Figure 1. Theoretical Framework

\section{Methodology}

To analyze to what extent strategic renewal is affected by human capital development, we conducted this study on the Egyptian 5-star hotels. We obtained the data from managers and supervisors of these hotels. Cairo hotels represent the research community where it was exposed to different crises and environmental changes; these factors require adapting to the changing environment. The five-star hotel class was determined because it possessed the financial resources and workforce to face crises through strategic changes. Especially as five-star hotels always strive for superiority and excellence.

The study population identified via random selection of ten 5-star hotels in Cairo, and they are: 1) Fairmont Nile City, 2) Kempinski Royal Towers, 3) Meridien Heliopolis, 4) Cairo Marriott, 5) Conrad Cairo, 6) Semiramis Intercontinental Cairo, 7) JW Marriott, 8) Dusit Thani Lakeview Cairo, and 9) Four Seasons Cairo, 10) and Grand Hyatt Cairo.

\subsection{Questionnaire Design and Validity}

Scales have been modified from previous studies. The elements were measured with 5point Likert scales, i.e., from: strongly disagree $=1$ to: strongly agree $=5$.

\subsubsection{Human Capital Development}

Sullivan and Steven (2013) defined human capital development as hiring, enhancing, and Making investments in employees through learning, training, coaching, mentoring, and organizational advancement. Therefore, human capital development is the independent variable in this research and was assessed by a 12 -item scale that covers three elements (training, coaching, and mentoring) from Preko's (2014) study.

\subsubsection{Strategic Renewal}

The strategic renewal construct was divided into three dimensions, strategic planning (depending on assessments by Sáez-Martínez and González-Moreno 2011 and Kreiser et al. 2010), exploitation, and explorative strategic renewal (depending on the assessment by Jansen et al. 2006). Strategic renewal as the dependent variable was assessed by a 15 -item scale to cover its three dimensions.

\subsubsection{Dynamic Capabilities}

Dynamic capability as a mediating variable was measured using a 7-item scale from the work of Kaur 2019.

\section{Data Analysis and the Statistical Methodology}

This section presents the data analysis part of our study. The Partial Least Square-Structural Equation Modeling (PLS-SEM) method has been used for analyzing the data and testing our hypotheses. The analysis of this paper was done using SPSS V. 23 for both descriptive and inferential statistics and Smart PLS V.3.3.3 for PLS-SEM analysis. The PLS-SEM is a broad strategy to test hypotheses and determine the relationship among exogenous and endogenous variables. Its purpose is to estimate the coefficients in a set of structural equations. The steps of the PLS-SEM analysis are (as Hair et al., 2017): 1) Specifying the Structural Model, 2) Defining the Measurement Models, 3) Data Collection and Examination, 4) PLS-SEM Model Estimation, 5) Assessing PLS-SEM Results for Measurement Model, 6) Assessing PLS-SEM Results for Structural Model and, 7) Interpretation of Results and Draw Conclusion. Next, the first section provides data collection, sample profile, and some descriptive statistics. And in the second section, we present the results of the PLS-SEM analysis. 


\subsection{Data Collection, Sample Profile, and Some Descriptive Statistics}

The questionnaires were distributed based on a simple sampling method and collected in the Egyptian hospitality industry. 310 questionnaires were distributed, and 204 usable samples were obtained after excluding incomplete questionnaires, yielding a $66 \%$ response rate from those who agree to participate.

Table 1 displays the frequencies of some demographic characteristics of respondents. For example, from Table 1, most respondents' ages were in the ranges 20-40 years (64.2\%), while $35.8 \%$ were more than 40 years. Moreover, the proportion of respondents with less than 15 years of experience is $66.7 \%$. And $86.8 \%$ of the respondents have bachelor's degrees.

Table 1. The frequency of demographic characteristics of respondents $(n=204)$

\begin{tabular}{|l|r|r|r|}
\hline Variable & Frequency & \% & Cumulative \% \\
\hline I. Age & 72 & 35.3 & 35.3 \\
\hline 20- 30 years old & 59 & 28.9 & 64.2 \\
\hline $31-$ 40 years old & 31 & 15.2 & 79.4 \\
\hline 41-50 years old & 42 & 20.6 & 100.0 \\
\hline More than 50 years old & & & 26.5 \\
\hline II. Experience $\quad 54$ & 26.5 & 40.7 \\
\hline Less than 5 years & 29 & 14.2 & 66.7 \\
\hline From 5 to less than 10 years & 53 & 26.0 & 84.3 \\
\hline From 10 to less than 15 years & 36 & 17.6 & 100.0 \\
\hline From 15 to less than 20 years & 32 & 15.7 & 5.9 \\
\hline 20 years and above & & & 92.6 \\
\hline III. Education level & 12 & 5.9 & 99.0 \\
\hline High School & 177 & 86.8 & 100.0 \\
\hline Bachelor's Degree & 13 & 6.4 & \\
\hline Master's Degree & 2 & 1.0 & \\
\hline Ph.D. or higher & & & \\
\hline
\end{tabular}

Table 2 presents some descriptive statistics for the variables. We can note that the data do not have significant variations because the values of the coefficients of variation (CV) are small (less than one) for all variables. The values of mean and median of all variables are close. Moreover, our sample can be considered large enough (204 cases) and no multivariate normality assumption violations because our sample is more than the recommended size of 200 cases (Medsker et al., 1994).

Table 2. Some Descriptive statistics

\begin{tabular}{|l|l|l|l|l|}
\hline Variable & Mean & Median & $\begin{array}{c}\text { Standard Deviation } \\
\text { (SD) }\end{array}$ & $\begin{array}{c}\text { Coefficient of } \\
\text { variation (CV) }\end{array}$ \\
\hline Training & 4.1683 & 4.3333 & 0.5088 & 0.122 \\
\hline Coaching & 3.5515 & 3.5000 & 0.7599 & 0.214 \\
\hline Mentoring & 3.5294 & 3.5000 & 1.0069 & 0.285 \\
\hline Strategic Planning & 4.4673 & 4.6667 & 0.4555 & 0.102 \\
\hline Exploitative Renewal & 4.0882 & 4.0000 & 0.5600 & 0.137 \\
\hline Explorative Renewal & 3.3419 & 3.5000 & 0.9290 & 0.278 \\
\hline
\end{tabular}

\subsection{PLS-SEM Analysis and Results}

In PLS-SEM analysis, the structural model illustrates the relationships between the factors. The measurement models, also known as the outer models, describe the relationships between the constructs and their variables. The model is estimated as in figure 2 . 


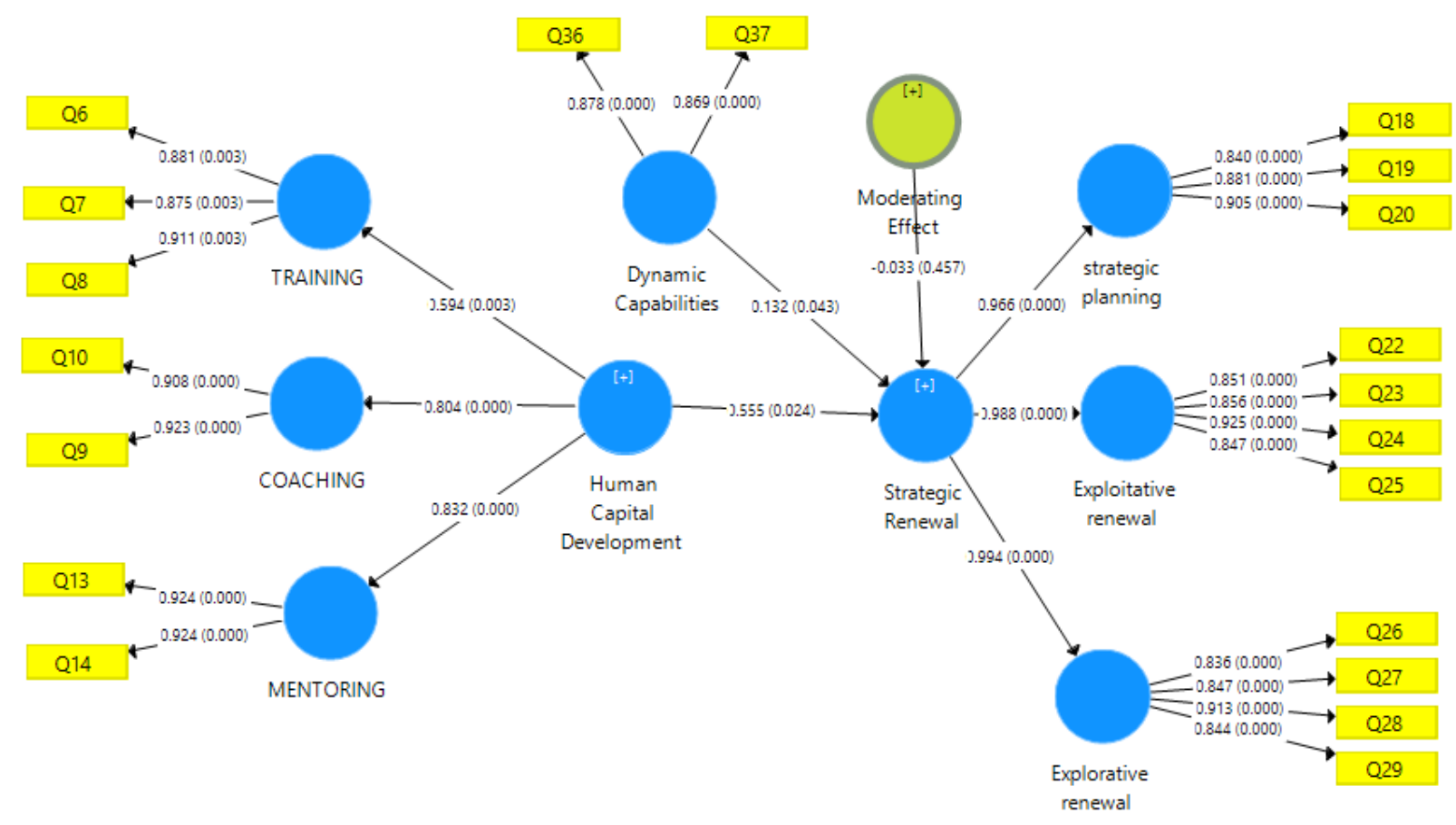

Figure 2. Path Coefficients with Corresponding P-values

\subsubsection{Assessment of Measurements Model}

The assessment of the reflective measurement models in PLS-SEM requires evaluating the internal consistency reliability, convergent validity, and discriminant validity.

\subsubsection{Internal Reliability and Validity}

The internal consistency reliability examines whether all the indicators associated with a construct can measuring it (Pallant, 2010). There are different ways to measure internal consistency. Cronbach's alpha is a statistical measure that is the most commonly used for this purpose. Cronbach's alpha provides the average correlation between all the indicators that belong to one construct. Despite its popularity, Cronbach's alpha is criticized for assuming that all the indicators have equal outer loadings (Hair et al., 2016). And that the number of indicators influences the calculation of Cronbach's alpha in that fewer items to produce a lower value, especially in scales with fewer than 10 (Pallant, 2010; Hair et al., 2016). Composite reliability measures the internal consistency while considering that each indicator has a different outer loading.

Table 3. Reliability and validity of measurement model analysis

\begin{tabular}{|l|r|r|r|}
\hline & Cronbach's Alpha & Composite Reliability & Average Variance Extracted (AVE) \\
\hline Human Capital Development & 0.782 & 0.854 & 0.503 \\
\hline TRAINING & 0.867 & 0.919 & 0.791 \\
\hline COACHING & 0.807 & 0.912 & 0.838 \\
\hline MENTORING & 0.829 & 0.921 & 0.854 \\
\hline Dynamic Capabilities & 0.705 & 0.865 & 0.762 \\
\hline Strategic Renewal & 0.963 & 0.967 & 0.729 \\
\hline Explorative renewal & 0.883 & 0.919 & 0.741 \\
\hline Exploitative renewal & 0.893 & 0.926 & 0.758 \\
\hline strategic planning & 0.848 & 0.908 & 0.767 \\
\hline
\end{tabular}

According to Hair et al. (2011), Xiong et al. (2015), and Garson (2016), the reliability of each construct was assessed using the calculations provided in Smart PLS software. Table 3 shows that all constructs have a reliability (Composite Reliability) score of approximately or more than 0.70, and for AVE, all constructs had reliability more than 0.5 . moreover, all Cronbach's Alpha values are more than 0.7 . 
Table 4. Item Loading

\begin{tabular}{|c|c|c|c|c|c|c|c|c|c|}
\hline Item & $\begin{array}{l}\text { Coachi } \\
\text { ng }\end{array}$ & $\begin{array}{l}\text { Dynamic } \\
\text { Capabilities }\end{array}$ & $\begin{array}{l}\text { Exploitative } \\
\text { Renewal }\end{array}$ & $\begin{array}{l}\text { Explorative } \\
\text { Renewal }\end{array}$ & $\begin{array}{l}\text { Human Capital } \\
\text { Development }\end{array}$ & $\begin{array}{l}\text { Mento } \\
\text { ring }\end{array}$ & $\begin{array}{l}\text { Strategic } \\
\text { Renewal }\end{array}$ & $\begin{array}{l}\text { Train } \\
\text { ing }\end{array}$ & $\begin{array}{l}\text { Strategic } \\
\text { Planning }\end{array}$ \\
\hline Q6 & & & & & & & & 0.881 & \\
\hline Q6 & & & & & 0.544 & & & & \\
\hline Q7 & & & & & & & & 0.875 & \\
\hline Q7 & & & & & 0.504 & & & & \\
\hline $\mathrm{Q8}$ & & & & & & & & 0.911 & \\
\hline Q8 & & & & & 0.536 & & & & \\
\hline Q9 & 0.923 & & & & & & & & \\
\hline Q9 & & & & & 0.765 & & & & \\
\hline Q10 & 0.908 & & & & & & & & \\
\hline Q10 & & & & & 0.706 & & & & \\
\hline Q13 & & & & & & 0.924 & & & \\
\hline Q13 & & & & & 0.771 & & & & \\
\hline Q14 & & & & & & 0.924 & & & \\
\hline Q14 & & & & & 0.767 & & & & \\
\hline Q18 & & & & & & & & & 0.84 \\
\hline Q18 & & & & & & & 0.787 & & \\
\hline Q19 & & & & & & & & & 0.881 \\
\hline Q19 & & & & & & & 0.838 & & \\
\hline Q20 & & & & & & & & & 0.905 \\
\hline Q20 & & & & & & & 0.907 & & \\
\hline Q22 & & & 0.851 & & & & & & \\
\hline Q22 & & & & & & & 0.856 & & \\
\hline Q23 & & & 0.856 & & & & & & \\
\hline Q23 & & & & & & & 0.854 & & \\
\hline Q24 & & & 0.925 & & & & & & \\
\hline Q24 & & & & & & & 0.918 & & \\
\hline Q25 & & & 0.847 & & & & & & \\
\hline Q25 & & & & & & & 0.806 & & \\
\hline Q26 & & & & 0.836 & & & & & \\
\hline Q26 & & & & & & & 0.845 & & \\
\hline Q27 & & & & 0.847 & & & & & \\
\hline Q27 & & & & & & & 0.856 & & \\
\hline $\mathbf{Q 2 8}$ & & & & 0.913 & & & & & \\
\hline Q28 & & & & & & & 0.913 & & \\
\hline Q29 & & & & 0.844 & & & & & \\
\hline Q29 & & & & & & & 0.804 & & \\
\hline Q36 & & 0.878 & & & & & & & \\
\hline Q37 & & 0.869 & & & & & & & \\
\hline
\end{tabular}

Table 4 shows outer loadings for the items of each construct. For all the reflective measurements, some values are under the threshold value of 0.7. However, we can retain items with loadings higher than 0.4 (Hair et al., 2017). And all items with loadings less than 0.4 were removed.

\subsubsection{Discriminant Validity}

Discriminant validity examines how much a construct differs from other constructs. Discriminant validity is usually established by examining cross-loadings or using Fornell-Larcker (1981) criterion. However, a recent study found that using the methods mentioned above is an unreliable way to establish discriminant validity. To overcome the shortcoming of cross-loadings and the Fornell-Larcker criterion, researchers should assess the Hetrotrait - Monotrait ratio (HTMT). 
Table 5. Hetrotrait - Monotrait Values

\begin{tabular}{|c|c|c|c|c|c|c|c|c|c|}
\hline & $\begin{array}{l}\text { Coac } \\
\text { hing }\end{array}$ & $\begin{array}{c}\text { Dynamic } \\
\text { Capabilitie } \\
\text { s }\end{array}$ & $\begin{array}{l}\text { Exploitativ } \\
\text { e Renewal }\end{array}$ & $\begin{array}{l}\text { Explorativ } \\
\text { e Renewal }\end{array}$ & $\begin{array}{c}\text { Human Capital } \\
\text { Development }\end{array}$ & $\begin{array}{l}\text { Ment } \\
\text { oring }\end{array}$ & $\begin{array}{l}\text { Strategic } \\
\text { Renewal }\end{array}$ & $\begin{array}{l}\text { Trai } \\
\text { ning }\end{array}$ & $\begin{array}{l}\text { Strategic } \\
\text { Planning }\end{array}$ \\
\hline \multicolumn{10}{|l|}{ COACHING } \\
\hline $\begin{array}{c}\text { DYNAMIC } \\
\text { CAPABILITIES }\end{array}$ & $\begin{array}{r}0.11 \\
4\end{array}$ & & & & & & & & \\
\hline $\begin{array}{c}\text { EXPLOITATIVE } \\
\text { RENEWAL }\end{array}$ & $\begin{array}{r}0.08 \\
9\end{array}$ & 0.159 & & & & & & & \\
\hline $\begin{array}{c}\text { EXPLORATIVE } \\
\text { RENEWAL }\end{array}$ & $\begin{array}{r}0.09 \\
2\end{array}$ & 0.188 & 0.808 & & & & & & \\
\hline $\begin{array}{l}\text { HUMAN CAPITAL } \\
\text { DEVELOPMENT }\end{array}$ & $\begin{array}{r}0.85 \\
5\end{array}$ & 0.146 & 0.756 & 0.760 & & & & & \\
\hline MENTORING & $\begin{array}{r}0.86 \\
1\end{array}$ & 0.055 & 0.127 & 0.127 & 0.877 & & & & \\
\hline $\begin{array}{l}\text { STRATEGIC } \\
\text { RENEWAL }\end{array}$ & $\begin{array}{r}0.08 \\
7\end{array}$ & 0.164 & 0.865 & 0.878 & 0.736 & 0.121 & & & \\
\hline TRAINING & $\begin{array}{r}0.09 \\
7\end{array}$ & 0.128 & 0.897 & 0.910 & 0.803 & 0.151 & 0.869 & & \\
\hline $\begin{array}{l}\text { STRATEGIC } \\
\text { PLANNING }\end{array}$ & $\begin{array}{r}0.08 \\
6\end{array}$ & 0.158 & 0.851 & 0.844 & 0.757 & 0.118 & 0.866 & $\begin{array}{r}0.81 \\
0\end{array}$ & \\
\hline
\end{tabular}

The HTMT value should be lower than 0.90 if the constructs in the model are conceptually very similar and lower than 0.85 if the constructs in the model are conceptually more different. Following these guides, all the constructs have HTMT values less than the defined threshold. Table 5 presents the constructs' HTMT values.

\subsubsection{Assessing the Structural Model}

The structural model, also known as the inner model, refers to the relationships between the constructs themselves, and its assessment includes evaluating the relationships between the constructs in the model. Researchers provided guidelines for assessing and reporting the structural model, including path coefficients, coefficient of determination (R2), Predictive Relevance (Q2), and Effect Size (f²).

\subsubsection{Path Coefficients}

Path coefficients refer to the estimates of the relationships between the model's constructs (Hair et al., 2014). Table 6 shows the model path coefficients associated with its T-statistic and P-values. It can be observed that Human Capital Development has a statistically significant effect on Strategic Renewal; since $\beta=0.555, \mathrm{t}=$ $2.437, \mathrm{P} \leq 0.001$, then $\mathrm{H} 1$ is confirmed. In addition, the Dynamic Capabilities have a statistically significant impact on Strategic Renewal, since $\beta=0.132, \mathrm{t}=2.108, \mathrm{P}=0.036$, then $\mathrm{H} 2$ is confirmed. 
Table 6. Model Path Coefficients

\begin{tabular}{|l|l|r|r|r|l|}
\hline Hypothesis & Path & Estimate & T-Statistic & \multicolumn{1}{l|}{ P-value } & Decision \\
\hline H1 & Human Capital Development -> Strategic Renewal & 0.555 & 2.437 & $\mathbf{0 . 0 1 5}$ & Confirmed \\
\hline H2 & Dynamic Capabilities -> Strategic Renewal & 0.132 & 2.108 & $\mathbf{0 . 0 3 6}$ & Confirmed \\
\hline H2 & Moderating Effect -> Strategic Renewal & -0.033 & 0.780 & $\mathbf{0 . 4 3 6}$ & Not confirmed \\
\hline
\end{tabular}

\subsubsection{Coefficient of Determination}

Coefficient of determination $\left(R^{2}\right)$ refers to the effect of independent variables on the latent dependent variables. Chin (1998) suggested that $R^{2}$ with $0.19,0.33$, or 0.67 are low, moderate, or high, respectively. The results of $R^{2}$ are reported in table 7 , the $R^{2}$ The model equals 0.33 , meaning that Human Capital Development and Dynamic Capabilities can explain about $33 \%$ of the variation in Strategic Renewal.

Table 7. Coefficient of Determination

\begin{tabular}{|l|r|r|r|}
\hline & \multicolumn{1}{|c|}{$\boldsymbol{R}^{\mathbf{2}}$} & Adjusted $\boldsymbol{R}^{\mathbf{2}}$ & \multicolumn{1}{|c|}{ Level } \\
\hline COACHING & 0.647 & 0.645 & moderate \\
\hline Exploitative renewal & 0.975 & 0.975 & high \\
\hline Explorative renewal & 0.988 & 0.988 & high \\
\hline MENTORING & 0.692 & 0.691 & high \\
\hline TRAINING & 0.353 & 0.350 & moderate \\
\hline strategic planning & 0.933 & 0.932 & high \\
\hline Strategic Renewal & 0.333 & 0.331 & moderate \\
\hline
\end{tabular}

\subsubsection{EFFECT SIZE $\left(f^{2}\right)$}

The $f^{2}$ effect size is the measure of how much impact the endogenous construct will have if an exogenous construct was removed from the model. A construct is considered to have a small effect if its $f^{2}$ value is between 0.02 and 0.14 , while it is considered to have a medium effect if its $f^{2}$ value is between 0.15 and 0.34 , and a large effect if its $f^{2}$ value $\geq 0.35$. Table 8 presents the $f^{2}$ the effect size of the constructs. The results illustrate that all constructs have large effects.

Table 8. $\mathrm{f}^{2}$ Effect Size

\begin{tabular}{|l|r|r|r|r|r|r|r|}
\hline & $\begin{array}{l}\text { COACHIN } \\
\text { G }\end{array}$ & $\begin{array}{l}\text { Exploitative } \\
\text { renewal }\end{array}$ & $\begin{array}{l}\text { Explorative } \\
\text { renewal }\end{array}$ & MENTORING & $\begin{array}{l}\text { Strategic } \\
\text { Renewal }\end{array}$ & TRAINING & $\begin{array}{l}\text { strategic } \\
\text { planning }\end{array}$ \\
\hline $\begin{array}{l}\text { Human Capital } \\
\text { Development }\end{array}$ & 1.831 & & & 2.251 & 0.458 & 0.546 & \\
\hline $\begin{array}{l}\text { Strategic } \\
\text { Renewal }\end{array}$ & & 39.625 & 81.042 & & & & 13.833 \\
\hline
\end{tabular}

\subsubsection{Predictive Relevance $\left(Q^{2}\right)$}

$Q^{2}$ the value indicates the model's out-of-sample predictive power. When a model is said to have a predictive power or predictive relevance, it can accurately predict data not used in the model estimation. Table 9 presents the $Q^{2}$ values obtained from the analysis. The values of $Q^{2}$ for Strategic Renewal in (Table 11) is higher than 0 , so it can be safely concluded that the model has a good predictive relevance. 
Table 9. Predictive Relevance test

\begin{tabular}{|l|r|r|r|}
\hline \multicolumn{1}{|l|}{ SSO } & \multicolumn{1}{l|}{ SSE } & $\mathbf{Q}^{\mathbf{2}}$ (=1-SSE/SSO) \\
\hline COACHING & 408.000 & 201.095 & 0.507 \\
\hline Dynamic Capabilities & 408.000 & 408.000 & 0.733 \\
\hline Exploitative renewal & 816.000 & 217.628 & 0.726 \\
\hline Explorative renewal & 816.000 & 223.986 & 0.560 \\
\hline Human Capital Development & 1428.000 & 1428.000 & 0.228 \\
\hline MENTORING & 408.000 & 179.431 & 0.257 \\
\hline Strategic Renewal & 2244.000 & 1732.202 & 0.710 \\
\hline TRAINING & 612.000 & 454.969 & \\
\hline strategic planning & 612.000 & 177.459 & \\
\hline
\end{tabular}

\subsubsection{Goodness of Fit of The Model}

Tenenhaus et al. (2005) proposed the Goodness of Fit (GOF) as a global fit indicator; it is the geometric mean of the average $R^{2}$ the AVE of the endogenous variables. The GOF index can be calculated as follow:

$$
G O F=\sqrt{\overline{R^{2}} \times \overline{A V E}}=\sqrt{0.703 \times 0.749}=0.726
$$

According to the GOF value (0.726), it can be safely concluded that the GOF of the model is large enough to be considered a sufficient valid global PLS model.

\section{Discussion and Conclusions}

The current study's primary goal is to evaluate the effect of human capital development on strategic renewal in the Egyptian hospitality industry. In addition, the study examined the moderating role of dynamic capacities on the relationship between human capital development and strategic renewal. We introduced two hypotheses to confirm the direct and indirect relationship between human capital development and strategic renewal. We found that Human Capital Development has a statistically significant effect on Strategic Renewal, verifying the first hypothesis. Consequently, H1 is confirmed. These findings are consistent with the studies of Jarvi \& Khoreva (2020). The second hypothesis of this study focus on the moderating role of the dynamic capabilities on the relationship between human capital development and strategic renewal. The findings observe that Dynamic Capabilities have a statistically significant impact on Strategic Renewal. Still, the Moderating Effect of dynamic capabilities not approved because the p-value of this path (0.436) more than 0.05 . The findings of this hypothesis are inconsistent with these of $\mathrm{Wu}$ et al. (2017).

\subsection{Theoretical Contribution}

This research includes two categories of theoretical contributions. The first is a conceptual model with statistical results that emphasizes the significance of human capital development for the strategic renewal of business enterprises in the Hospitality field of developing countries. Human capital development has previously been highlighted, but its impact on strategic renewal has not been extensively investigated, particularly in the hospitality field (Shah et al., 2019). Second, dynamic capabilities as a moderator were focused on Previously, but the relationship established in this study has not been extensively investigated in the hotel industry.

\subsection{Managerial Implications}

Besides the conceptual contribution, this study provides valuable insights for decision-makers. First, the current research recommends that hotel managers consider human capital development and present it as a vital part of strategy formulation. This research further suggests that managers should emphasize the dynamic capacities of the enterprise. Thus, it is effortless to adapt to the transformations and uncertainties effectively. By using dynamic capabilities, the company is expected to grow, adapt, and reconfigure its capabilities to ensure the accomplishment of strategic renewal in the hotel industry.

\section{References}

Agarwal, R., \& Helfat, C. E. (2009). Strategic renewal of organizations. Organization Science, 20, 281-293. https://doi.org/10.1287/orsc. 1090.0423

Alo, O. (2000). Managing the human capital for national development. 5th Annual public lecture, Institute of Personnel Management of Nigeria.

Al-Shuwaikhi, A. (2015). Egyptian tourism, a fifth year of the crisis.

Barney, J. B. (1986). Organizational culture: can it be a source of sustained competitive advantage? Academy of Management Review, 11(3), 656-665. https://doi.org/10.5465/amr.1986.4306261 
Barney, J. B. (1991). Firm resources and sustained competitive advantage. Journal of Management, 17, 99-120. https://doi.org/10.1177/014920639101700108

Barney, J. B. (2001). Resource-based theories of competitive advantage: a ten-year retrospective on the resource-based view, Journal of Management, 27, 643-650. https://doi.org/10.1177/014920630102700602

Becker, G. (1962). Investment in Human Capital: A Theoretical Analysis. Journal of Political Economy, 70(5) 9-49. https://doi.org/10.1086/258724

Becker, G. S. (1964). Human capital. New York: Columbia University Press.

Benos, N., \& Zotou S. (2014). Education and economic growth: a meta-regression analysis. World Dev., 64, 669-689. https://doi.org/10.1016/j.worlddev.2014.06.034

Bosma, N. S., van Praag, C. M., Thurik, A. R., \& de Wit, G. (2004). The value of human and social capital investments for the business performance of startups. Small Business Economics, 23, 227-236. https://doi.org/10.1023/B:SBEJ.0000032032.21192.72

Burgelman, R. A. (1991). Intra organizational ecology of strategy making and organizational adaptation: theory and field research. Organization Science, 2, 239-262.

Chin, W. W. (1998). The partial least squares approach to structural equation modeling. Modern methods for business research, 295(2), 295-336. https://doi.org/10.1287/orsc.2.3.239

Chowdhury, D. S. (2002). Turnarounds: a stage theory perspective. Canadian Journal of Administrative Sciences, 19(3), 249-266. https://doi.org/10.1111/j.1936-4490.2002.tb00271.x

Coleman, J. (2009). Social capital in the creation of human capital. Taylor and Francis Inc., (2009), 17-42. https://doi.org/10.1086/228943

Crossan, M. M., \& Berdrow, I. (2003). Organizational learning and strategic renewal. Strategic Management Journal, 24(11), 1087-1105. https://doi.org/10.1002/smj.342

Crossan, M. M., Lane, H. W., \& White, R. E. (1999). An organizational learning framework: from intuition to institution. Academy of Management Review, 24, 552-537. https://doi.org/10.5465/amr.1999.2202135

Cummings, G. G., MacGregor, T., Davey, M., Lee, H., Wong, C. A., Lo, E., \& Stafford, E. (2010). Leadership styles and outcome patterns for the nursing workforce and work environment: a systematic review. International Journal of Nursing Studies, 47(3), 363-385. https://doi.org/10.1016/j.ijnurstu.2009.08.006

Danneels, E. (2002). The dynamics of product innovation and firm competences, Strategic Management Journal, 23, 1095-1121. https://doi.org/10.1002/smj.275

Dutta, S. K. (2013). Ambidexterity as a mediating variable in the relationship between dynamism in the environment, organizational context, and strategic renewal. Jindal Journal of Business Research, 2(1), 27-41. https://doi.org/10.1177/2278682114533177

Dzinkowski, R. (2000). The value of intellectual capital. Journal of Business Strategy, 2000.

Easterby-Smith, M., \& Prieto, I. M. (2008). Dynamic capabilities and knowledge management: an integrative role for learning? British Journal of Management, 19(3), 235-249. https://doi.org/10.1111/j.1467-8551.2007.00543.x

Eisenhardt, K. M., \& Martin, J. A. (2000). Dynamic capabilities: what are they? Strategic management journal, john wiley \& sons, $l(21), 1105-1121$. https://doi.org/10.1002/1097-0266(200010/11)21:10/11\%3C1105::AID-SMJ133\%3E3.0.CO;2-E

Felicio, J. A., Couto, E., \& Caiado, J (2014). Human Capital, social capital, and organizational performance. Management Decision, 52(2), 350-364. https://doi.org/10.1108/MD-04-2013-0260

Fix, B. (2018). The trouble with human capital theory. York University, Toronto, Canada. https://doi.org/10.31235/osf.io/ax6k7

Flier, B., Van Den Bosch, F. A. J., \& Volberda, H. (2003). Coevolution in the strategic renewal behavior of British, Dutch, and French financial incumbents: interaction of environmental selection, institutional effects, and managerial intentionality. Journal of Management Studies, 40, 2163-2187. https://doi.org/10.1046/j.1467-6486.2003.00416.x

Florin, J., Lubatkin, M., \& Schulze, W. (2003). A social capital model of high growth ventures. Academy of Management Journal, 46(3), 374-384. https://doi.org/10.2307/30040630 
Floyd, S. W., \& Lane, P. J. (2000). Strategizing throughout the organization: managing role conflict in strategic renewal. Academy of Management Review, 25, 154-177. https://doi.org/10.5465/amr.2000.2791608

Fornell, C., \& Larcker, D. F. (1981). Evaluating structural equation models with unobservable variables and measurement error. Journal of marketing research, 18(1), 39-50. https://doi.org/10.1177/002224378101800104

Garavan, T., Shanahan, V., Carbery, R., \& Watson, S. (2016). Strategic human resource development: Towards a conceptual framework to understand its contribution to dynamic capabilities. Human Resource Development International, 19(4), 289-306. https://doi.org/10.1080/13678868.2016.1169765

Garson, G. D. (2016). Partial Least Squares: Regression and Structural Equation Models. Asheboro, NC, USA: Statistical Associates Publishers. Retrieved from https://www.smartpls.com/resources/ebook_on_pls-sem.pdf

Goldin, C. (2016) Human capital. In Diebolt C, Haupert M (eds) Handbook of cliometrics. Heidelberg, Berlin. https://doi.org/10.1007/978-3-642-40406-1_23

Grant, R. M. (1996). Toward a knowledge-based theory of the firm. Strategic Management Journal, Summer Special Issue, 17, 109-122. https://doi.org/10.1002/smj.4250171110

Guth, W. D., \& Ginsberg, A. (1990). Guest editors' introduction: corporate entrepreneurship. Strategic Management Journal, 11, 5-15.

Hair, J. F., Black, W. C., Babin, B. J., \& Anderson, R. E. (2014). Multivariate Data Analysis (7th ed.) Pearson.

Hair, J. F., Celsi, M., Money, A., Samouel, P., \& Page, M. (2016). Essentials of Business Research Methods. New York: Routledge. https://doi.org/10.4324/9781315704562

Hair, J. F., Hult, G. T., Ringle, C. M., \& Sarstedt, M. (2017). A Primer on Partial Least Squares Structural Equation Modeling (PLS-SEM) (2nd ed.). Los Angeles, CA: SAGE. https://doi.org/10.15358/9783800653614

Hair, J. F., Ringle, C. M., \& Sarstedt, M. (2011). PLS-SEM: Indeed, a silver bullet. Journal of Marketing theory and Practice, 19(2), 139-152. https://doi.org/10.2753/MTP1069-6679190202

Hair, J. F., Sarstedt, M., Hopkins, L., \& Kuppelwieser, V. G. (2014). Partial Least Squares Structural Equation Modeling (PLS-SEM): An Emerging Tool in Business Research. European Business Review, 26(2), 106-121. https://doi.org/10.1108/EBR-10-2013-0128

Hansen, M. T. (1999). The search-transfer problem: the role of weak ties in sharing knowledge across. https://doi.org/10.2307/2667032

Hargadon, A., \& Sutton, R. I. (1997). Technology brokering and innovation in a product development firm. Administrative Science Quarterly, 42(4), 716-749. https://doi.org/10.2307/2393655

Helfat, C. E., \& Raubitschek R. S. (2000). Product sequencing: co-evolution of knowledge, capabilities and products. Strategic Management Journal 21, 961-979. https://doi.org/10.1002/1097-0266(200010/11)21:10/11\%3C961::AID-SMJ132\%3E3.0.CO;2-E

Honig, B. (2001). Human capital and structural upheaval: A study of manufacturing firms in the West Bank. Journal of Business Venturing, 16, 575-594. https://doi.org/10.1016/S0883-9026(99)00060-9

Hurst, D. (1995). Crisis and renewal: Ethical anarchy in mature organizations. Business Quarterly, 60(2), 32-41.

Jansen, J. J. P., Van D. B., \& Volberda, H. W. (2006). Exploratory innovation, exploitative innovation, and performance: effects of organizational antecedents and environmental moderators. Management Science, 52(11), 1661-1674. https://doi.org/10.1287/mnsc.1060.0576

Jarvi, K., \& Khoreva, V. (2020). The role of talent management in strategic renewal. Employee Relations, 42(1), 75-89. https://doi.org/10.1108/ER-02-2018-0064

Kaur, V. (2019). Knowledge-Based Dynamic Capabilities the Road Ahead in Gaining Organizational Competitiveness. The University of Texas at Dallas Richardson, TX, USA. ISSN 2197-5698 ISSN 2197-5701 (electronic). https://doi.org/10.1007/978-3-030-21649-8

Kreiser, P. M., Marino, L., Davis, J., Tang, Z., \& Lee, C. (2010). Firm-level entrepreneurship: the role of proactiveness, innovativeness and strategic renewal in the creation and exploration of opportunities. Journal of Developmental Entrepreneurship, 15(2), 143-163. https://doi.org/10.1142/S1084946710001488 
Kuznetsova, I. G., Goloshchapova, L. V., Ivashina, N. S., Shichiyakh, R. A., Petrova, L. I., \& Tkachev, B. P. (2019). The paradigm of human capital development capable of adapting innovations in the transition to a digital economy. International Journal of Civil Engineering and Technology, 10(2), 1408-1417

Martin-Rios, C. (2020). Unlocking Sustainable Strategic Renewal After COVID-19: Opportunities for Hospitality. Hospitality Net. Retrieved November 7, 2020, from

https://www.hospitalitynet.org/opinion/4098309.html

Medsker, G. J., Williams, L. J., \& Holahan, P. J. (1994). A review of current practices for evaluating causal models in organizational behavior and human resources management research. Journal of Management, 20, 439-64. https://doi.org/10.1177/014920639402000207

Mielcarek, P. (2018). The strategic renewal process - the challenge of creating and capturing value. Management sciences, 23(4). https://doi.org/10.15611/ms.2018.4.04

Mohamed, A., Jones, E., Dawood, A., \& Fayed, H. (2016). A proposed model for managing demand downturn for hotel rooms: evidence from Cairo hotels. Minia Journal of Tourism and Hospitality Research, 1(2), 101-126.

Pallant, J. (2010). SPSS survival manual (4th ed.). England: McGraw-Hill Education.

Pisano, G. P. (1994). Knowledge, integration, and the locus of learning: an empirical analysis of process development. Strategic Management Journal, Winter Special Issue. 15, 85-100. https://doi.org/10.1002/smj.4250150907

Ployhart, R. E., Nyberg, A. J., Reilly, G., \& Maltarich, M. A. (2014). Human capital is dead; long live human capital resources. Journal of Management, 40(2), 371-398. https://doi.org/10.1177/0149206313512152

Porter, M. E. (1996). What is strategy? Harvard Business Review, 74(6), 61-78.

Preko, A. (2014). Assessing the impact of human capital development on effective work performance at selected departments in the college of arts and social sciences (knust). Master of business administration (human resource management). School of business, knust.

Sáez-Martínez, F. J., \& González-Moreno, Á. (2011). Strategic renewal, cooperation, and performance: a contingency approach. Journal of Management and Strategy, 2(4), 43-55. https://doi.org/10.5430/jms.v2n4p43

Schmitt, A., Barker III, V. L., Raisch, S., \& Whetten, D. (2016). Strategic renewal in times of environmental scarcity. Long Range Planning, 49(3), 361-376. https://doi.org/10.1016/j.lrp.2015.08.004

Schmitt, A., Raisch, S., \& Volberda, H. W. (2018). Strategic renewal: Past research, theoretical tensions, and future challenges. International Journal of Management Reviews, 20(1), 81-98.

Schultz, T. W. (1961) Investment in human capital. Am Eco Rev. 51, 1-17. https://doi.org/10.1111/ijmr.12117

Sexton, D. L., \& Upton, N. B. (1985). The entrepreneur: A capable executive and more. Journal Business Venturing, 1, 129-140. https://doi.org/10.1016/0883-9026(85)90012-6

Shah, H. A., Yasir, M., Majid, A., \& Javed, A. (2019). Promoting strategic performance through strategic orientation and strategic renewal. Management Decision, 58(2), 376-392. https://doi.org/10.1108/MD-04-2019-0536

Smith, V. (2010). Enhancing employability: Human, cultural, and social capital in an era of turbulent unpredictability. Human Relations, 63(2), 279-300. https://doi.org/10.1177/0018726709353639

Sonnentag, S., \& Frese, M., (2002). Performance concepts and performance theory. In S. Sonnentag (Ed.), Psychological management of individual performance: A handbook in the psychology of management in organizations. pp. 3-25. Chichester: Wiley.

Stopford, J. M., \& Baden-Fuller, C. (1994). Creating corporate entrepreneurship. Strategic Management Journal. 15, 521-536. https://doi.org/10.1002/smj.4250150703

Sullivan, A., \& Steven, M. S. (2003). Economics principles in action. Upper Saddle River, New Jersey: Pearson Prentice.

Teece, D. J., Pisano, G., \& Shuen, A. (1997). Dynamic capabilities and strategic management. Strategic Management Journal, 18(7), 509-533. https://doi.org/10.1002/(SICI)1097-0266(199708)18:7\%3C509::AID-SMJ882\%3E3.0.CO;2-Z 
Tenenhaus, M., Esposito Vinzi, V., Chatelinc, Y. M., \& Lauro, C. (2005). PLS Path Modelling, Computational Statistics \& Data Analysis, 48(1), 159-205. https://doi.org/10.1016/j.csda.2004.03.005

Unger, J. M., Rauch, A., Frese, M., \& Rosenbusch, N. (2011). Human capital and entrepreneurial success: A meta-analytical review. Journal of Business Venturing. https://doi.org/10.1016/j.jbusvent.2009.09.004

Verbeke, A., Chrisman, J. J., \& Yuan, W. (2007). A note on strategic renewal and corporate venturing in the subsidiaries of multinational enterprises. Entrepreneurship Theory and Practice, 31, 585-600. https://doi.org/10.1111/j.1540-6520.2007.00189.x

Volberda, H., Baden-Fuller, C., \& Van Den Bosch, F. A. J. (2001). Mastering strategic renewal: mobilizing renewal journeys in multi-unit firms. Long Range Planning, 34, 159-178. https://doi.org/10.1016/S0024-6301(01)00032-2

Walas-Trębacz, J. (2008). Conditions for the success of strategic revitalization of the enterprise. Scientific Journals of Management, 772, 5-114.

Warner, K. S., \& Wager, M. (2019). Building dynamic capabilities for digital transformation: An ongoing process of strategic renewal. Long Range Planning, 52(3), 326-349. https://doi.org/10.1016/j.lrp.2018.12.001

Wernerfelt, B. (1984). A resource-based view of the firm. Strategic Management Journal, 5, 171-180. https://doi.org/10.1002/smj.4250050207

Womack, J. P., Jones, D. T., \& Roos, D. (1991). The Machine that Changed the World: The Story of Lean Production. HarperCollins: New York.

Wu, S. H., Lin, L. Y., \& Hsu, M. Y. (2017). Intellectual capital, dynamic capabilities, and innovative performance of organizations. International Journal of Technology Management, 39(3-4), 279-296. https://doi.org/10.1504/IJTM.2007.013496

Xiong, B., Skitmore, M., \& Xia, B. (2015). A critical review of structural equation modeling applications in construction research. Automation in construction, 49, 59-70. https://doi.org/10.1016/j.autcon.2014.09.006

Zacharakis, A. L., \& Meyer, D. G. (2000). The potential of actuarial decision models: Can they improve the venture capital investment decision? Journal of Business Venturing, 15, 323-346. https://doi.org/10.1016/S0883-9026(98)00016-0

Zaytoun, M., Heiba, A., \& Abdelhakim, M. (2010). Implications of the Global Financial and Economic Crisis on the Tourism Sector in Egypt. International Labour Organization and Egyptian Cabinet Information and Decision Support Center Cairo. Retrieved From http://www.oit.org/wcmsp5/groups/public/---Africa/---ro-addis_ababa/---sro-cairo/documents/publication/c ms_243798.pdf

\section{Copyrights}

Copyright for this article is retained by the author(s), with first publication rights granted to the journal.

This is an open-access article distributed under the terms and conditions of the Creative Commons Attribution license (http://creativecommons.org/licenses/by/4.0/). 